\title{
Fennel (Foeniculum vulgare) leaf infusion effect on mammary gland activity and kidney function of lactating rats
}

\author{
NAJDA RIFQIYATI, ANA WAHYUNI \\ Program of Biology, Faculty of Science and Technology, Universitas Islam Negeri Sunan Kalijaga. Jl. Marsda Adisucipto No.1, Sleman 55281, \\ Yogyakarta, Indonesia. Tel.: +62-274-519739, Fax.: +62-274-540971, `email: nada_gusna@ yahoo.com.
}

Manuscript received: 29 October 2018. Revision accepted: 18 April 2019.

\begin{abstract}
Rifqiyati N, Wahyuni A. 2019. Fennel (Foeniculum vulgare) leaf infusion effect on mammary gland activity and kidney function of lactating rats. Nusantara Bioscience 11: 101-105. Fennel (Foeniculum vulgare Mill) leaf, traditionally, is believed to have a potential in increasing and smoothing breast milk production. This study aimed to determine the effect of fennel leaf infusion on milk production and to know the side effects of its use. The material used in the research was infusion of fennel leaves (Foeniculum vulgare Mill) collected from Kopeng, Central Java. The research utilized 12 female rats each with 5 newborns off springs. The experiment was designed in Completed Random Design (CRD) with 4 treatments and 3 replications. Histological preparation of mammary glands was set using paraffin method with HE staining. Kidney function was observed through uric acid level in the blood. The results showed that the diameter of lactiferous ducts and of its lumen diameter were significantly influenced by 15 days fennel leaf infusion treatment. The largest lactiferous duct diameter observed was on P3 treatment group $(452.97 \pm 75.033 \mu \mathrm{m})$ and the smallest was observed in control groups $(273.17 \pm 38.746 \mu \mathrm{m})$. The numbers of active alveoli observed in treatment groups, i.e., in P1 $(20 \mathrm{~g} / 300 \mathrm{~mL})$, P2 $(40 \mathrm{~g} / 300$ $\mathrm{mL})$, and P3 $(60 \mathrm{~g} / 300 \mathrm{~mL})$, increased than inactive alveoli. The blood uric acid level observed was 4.0-4.6 $\mathrm{mg} / \mathrm{dl}$. The results suggested that the infusion of fennel leaf with a treatment dose of $60 \mathrm{~g}$ infusion in $300 \mathrm{~mL}$ distilled water administered for 15 days can significantly increase the diameter of lactiferous lumen of female rat mammary glands, and increase the diameter of the alveoli and the number of active alveolar mammary glands. Histological picture of mammary gland also showed that the female rats treated with dose of $60 \mathrm{~g}$ infusion per $300 \mathrm{~mL}$ aquadest increased milk secretion and than the other treatment groups. The treatment also showed no significant side effects.
\end{abstract}

Keywords: Alveolus, fennel, Foeniculum vulgare, leaf, kidney, mammary gland, lactiferous duct

\section{INTRODUCTION}

Breast milk is a very important nutrient for neonatal. Even in the Qur'an the mention of the importance of breastfeeding is also mentioned. A high appreciation is given for a mother who gives breast milk to her child. This is explained in the Qur'an, S. Luqman: 14 which means "And We command the people (do good) to their parent; his mother had conceived him in an increasingly weak condition and weaned him in two years ". Many mothers know the importance of breast milk, however, do not give exclusive breastfeeding to newborn babies. Rapid assessment resulted from the ministry of health, the success of national exclusive breastfeeding is $33.6 \%$ and According to WHO bank data at $35 \%$ in 2012 (Kurniawan 2013). Based on these problems, it is necessary to have a solution to increase milk production, so the children can grow and develop optimally and become a superior generation.

Vegetables consumption is one alternative food source that can stimulate and increase the milk production. Fennel plant (Foeniculum vulgare Mill) is a medicinal plant (phytoestrogens) that can be used both seeds and leaves. Many studies that report fennel seeds can be used to cure various diseases and affect hormonal work such as reproductive hormones. Al Sudany et al. (2014) study showed that administration of $10 \%$ fennel seeds for 20 days gave an effect such as the hormone prolactin in increasing milk secretion.

In Indonesia, fennel is a vegetable that can grow to an altitude of $1800 \mathrm{~m}$ above sea level and is better grown in the highlands (Dalimartha 2000). People in slope of Merbabu mountain believe this vegetable can increase milk secretion is like Katuk (Sauropus androgynus) leaf. However, this fennel leaf is only found in mountainous regions and has a distinctive taste (medicinal aroma) so that not everyone able and wants to consume it in large quantities as vegetables or vegetables. Based on the study of nutrient and phytochemical content carried out previously, fennel (Foeniculum vulgare Mill) leaves contained $13.10 \%$ water, $14.17 \%$ ash, $22.60 \%$ protein, $1.47 \%$ fat and $16.42 \%$ crude fiber (Rifqiyati 2016). The highest nutrient content is protein $(22.60 \%)$ which is higher when compared to protein in katuk leaves (4.8\%) and papaya leaves (8\%). Permana's study (2008) shows that the addition of protein consumption or an increase in the quality of protein in food has a positive effect on increasing the volume of milk.

Fennel is one of the galaktogogum plants from traditional medicine Javan et al (2017). The flavonoid content in fennel plants has the effect of galaktogogum which works the same as oxytocin in the uterus of pregnant and non-pregnant mice. The hormone oxytocin and prolactin play a role in increasing milk production. 
Prolactin plays a role in the synthesis of milk, while oxytocin activity in the mammary gland causes contraction of myoepithelial cells, so that milk will be pushed towards the milk ducts. The administration of fennel infusion containing flavonoids in female mice can increase prolactin levels. This is because the infusion of fennel leaves works as a dopamine antagonist. Increased prolactin levels can play a role in stimulating lactation (Kharisma et al. 2011).

This research was conducted to provide alternative solutions to increase milk production and increase the usability of fennel leaves on the problem of lactation, because so far what is widely used from fennel (Foeniculum vulgare Mill) plants is the fruit and seeds. In addition to exploring the potential, we also need to consider the side effects of the use of this fennel leaf infusion. Regular administration of infusion at a certain dose of herbal medicine and at certain times can cause interference with kidney function and liver function.

\section{MATERIALS AND METHODS}

\section{Materials}

The material used in this study was adult fennel leaves (Foeniculum vulgare Mill) obtained from farmers in the Merbabu mountains, namely in Kopeng Village, Central Java. The test animals used 12 lactation rats with each nursing mice 5 of jouvenile., chloroform, bouin, stratified alcohol, xylol, paraffin, Hematoxylin Eosin (HE) dye, and entellan.

\section{Procedures}

The experimental design used in this study was a completely randomized design which consisted of 4 treatments and in each treatment there were 3 replications. Every enclosure consisted of a mother rat and five jouvenile. The infusion was prepared by cutting fennel leaves into small pieces (4-5 centimeters) and put in oven with the temperature $40^{\circ} \mathrm{C}$ for a few days until reaching a constant weight. The dry leaves then were grinded and sifted until finely powdered. The powder then wasweighed about 20 grams to make the $20 \mathrm{~g} / 300 \mathrm{~mL}$ infusion (P1), 40 $\mathrm{g}$ for $40 \mathrm{~g} / 300 \mathrm{~mL}$ infusion (P2) and 60 grams for $60 \mathrm{~g} / 300$ $\mathrm{mL}$ infusion $(\mathrm{P} 3)$. The powder was put in beaker glasses and then soaked in $300 \mathrm{~mL}$ water. The mixture was heated to $90{ }^{\circ} \mathrm{C}$ on a hotplate for 15 minutes, then filteredtwice to achieve $100 \mathrm{~mL}$ infusion (Pidada and Suhargo 2009). Each lactating rat was given an infusion of fennel leaves orally. Giving doses was done twice a day, which was every morning and evening (1 $\mathrm{mL}$ each) for 15 days. Starting from the $3^{\text {rd }}$ day of lactation until the 17 days of lactation.

The method used to determine the increase in milk secretion was by measuring the lactoferous duct diameter and the number of mammary gland active alveoli from the mammary gland histology. On the $16^{\text {th }}$ day after the treatment, the juveniles were separated from their mothers for 2 hours, so that the mammary glands became full of milk. The mother rats were anasthetized with cloroform and than weresacrificed to take nipples and mammary glands for histological preparations (Pidada and Suhargo
2007). Histological preparations was done using the paraffin method with Haematoxillin Eosin staining (Kiernan 1990). Kidney function measured by looking at uric acid levels to determine if there was a damage in the kidney after administration of fennel leaves with various doses for 15 days. Measuring uric acid levels in the blood was done by taking blood $(1 \mathrm{~mL})$ in the vein section of the rat's tail on the $16^{\text {th }}$ day after treatment, then measured using the Easy Touch blood uric acid test meter.

\section{Data analysis}

The data obtained were analysed by one-way ANOVA and if there was a significant effect followed by DMRT test with a confidence level of $95 \%$

\section{RESULTS AND DISCUSSION}

Based on the data obtained from this study, the infusion treatment of fennel leaves has a positive influence on the lactoferous duct diameter and lumen. The use of infusions or extracts of water from fennel is more effective than methanol extract (Benlafya et al. 2015). Infusion of fennel leaves for 15 days can increase the diameters of the alveoli and lumen (Table 1). This is because fennel leaves are one of the alternative herbal galaktogagum (Patel et al. 2013). The compound anethole of fennel is considered to be an active esstrogenic agent. The effect of extract fennel seeds was increased nucleic acid and protein concentration on mammary glands and oviduct of cstrated rats (Devi et al. 1985).

The results of statistical tests using one-way ANOVA on the $95 \%$ confidence level showed a significant effect in the lumen diameter of the lactiferous duct between treatment groups with a significance level of $p<0.05$. The analysis was continued with the DMRT test and began to show significant differences in the P2 treatment group. This study also showed an increase in alveolar diameter from P2 treatment and the largest was alveolar diameter in $\mathrm{P} 4$, but it was not significant when compared with controls and other treatments excretion of milk.

Protein of fennel leaves can be increased milk secretion. Neville (1998) said that Increasing the supply of food protein will be increased levels of amino acids in the blood which help the activity of lactogenesis. Lactogenesis happened on alveolus of mammary gland. Fennel leaves have 22,60\% protein and 208,06 Cal/g (Rifqiyati 2014). Proteins with 18 amino acids content in mushroom (Pleurotus ostreatus) can stimulate an increase in milk secretion followed by an increase in diameter alveolus because the alveoli is enlarged (Pidada and Suhargo 2007).

Table 1. Parameters measured in the Mammary gland

\begin{tabular}{lcc}
\hline \multirow{2}{*}{ Doses } & \multicolumn{2}{c}{ Diameter $(\boldsymbol{\mu m})$} \\
\cline { 2 - 3 } & Lactiferous Lumen & Alveolus \\
\hline $0 \mathrm{~g} / 300 \mathrm{~mL}$ & $156.52 \pm 19.091^{\mathrm{a}}$ & $125.13 \pm 25.712^{\mathrm{a}}$ \\
$20 \mathrm{~g} / 300 \mathrm{~mL}$ & $202.06 \pm 13.111^{\mathrm{ab}}$ & $116.22 \pm 17.148^{\mathrm{a}}$ \\
$40 \mathrm{~g} / 300 \mathrm{~mL}$ & $245.79 \pm 21.603^{\mathrm{b}}$ & $130.52 \pm 13.082^{\mathrm{a}}$ \\
$60 \mathrm{~g} / 300 \mathrm{~mL}$ & $339.10 \pm 52.670^{\mathrm{c}}$ & $141.44 \pm 18.013^{\mathrm{a}}$ \\
\hline
\end{tabular}


Some active compounds (phytochemicals) contained in fennel leaves are thought to be able to stimulate reproductive hormones in secreting milk. Fennel is galactogagum plant. An infusion made from leaves fennel is drunk for milk stimulant pregnant women in south Africa (Badgujar et. al. 2014). Galactogagum increases the proliferation of lactoferous ducts by increasing milk production (Dhumal et al. 1989). Flavonoid is fitoestrogen which has estrogen efect on mammary gland. Estrogen increase proliferation of ductus and lobulus mammary gland epitels (Meiyanto et al. 2008). Alkaloids and flavonoids can increase the production of the prolactin hormone.

Prolactin plays a role in the synthesis of milk in epithelial cells in the alveolus. $\alpha$-adrenergic receptors contained in the mammary gland ducts that work synergistically with the hormone oxytocin in milk ejection. Kharisma et al. (2011) said that saponin and alkaloid in infution of Carica papaya L. young fruits can be increased milk production. The effects given from this fennel leaf infusion are similar to the effect of Wungu leaf Graptophyllum pictum L.) which can inhibit mammary gland atrophy (Pidada and Suhargo 2009). They said that Wungu leaf can inhibit the mammary gland atrophy seen from the morphometry of the milk ducts and nipples.

Lactogagum of fennel acts as estrogen. The use of highdose fennel seeds in a few days can increase milk production and improve the digestion of mothers and babies. administration of fennel seeds in doses that are too high for a long time can be decreased milk production because it provided a negative feetback for prolactin mechanism. The mechanism of stimulation of hormone is also the basis for increasing milk production. The hormone estrogen will stimulate the growth of lactoferous ducts and milk gland alveoli. Mammary glands in some species like cats, rats and pigs, it is evident that progesterone only plays a role in developing the alveoli, while the estrogen hormone plays a role in developing the milk ducts in the gland. In some species, estrogen can stimulate the growth of milk ducts and mammary gland alveoli . Together with progesterone, estrogen always stimulates the growth of milk ducts and milk gland alveoli (Partodihardjo 1992).

In this study it was shown that the infusion of fennel leaves can significantly increase the lactoferous duct diameter. In addition, the amount of active alveoli in the mammary gland also affected the amount of secretion of milk produced. The number of mammary gland active alveoli in the control group was lower than that of the inactive alveoli. Unlike the case in the infusion treatment group of fennel leaves. In doses $20 \mathrm{~g} / 300 \mathrm{~mL}, 40 \mathrm{~g} / 300$ $\mathrm{mL}$ and $60 / 300 \mathrm{~mL}$, the results of the number of active alveoli were higher than inactive alveous (Figure 1).

This study showed that the treatment of fennel infusion with different doses also affects the number of alveoli that actively secrete milk. The result is the same as Permana (2008) where proteins contained in torbangun leaves can stimulate the increase of milk secretion. This can be seen from the increase in the number of active alveoli. The number of active alveoli increases with increasing infusion dose concentration given fennel leaves. The increase in milk production is influenced by the presence of secondary metabolites (flavonoids) contained in fennel leaves, also caused by the presence of alkaloids. Kharisma et al. (2011) suggested that the content of saponins and alkaloids contained in Carica papaya L. increase milk production in mothers of mice during lactation. Alkaloids can increase the production of the hormone prolactin which plays a role in the synthesis of milk in the mammary gland. The effect of fennel leaves is similar to the effect of fennel seeds carried out by Al Sudany et al. (2014) which is to increase milk secretion in lactating mice. But the cells that are affected are different. Giving fennel seeds $10 \%$ for 20 days gives the effect of hyperplasia in alveolar epithelial cells. the treatment of fennel leaves for 15 days increased the number of active alveoli and the lactoferous duct diameter increased significantly, but not significant for the alveolar diameter increased. In addition to the active compounds contained in the infusion of fennel leaves, milk production is also influenced by the nutritional content of the fennel leaf itself. The quality and quantity of milk is closely related to various factors, namely genetic, food, hormonal, environmental and individual health (Brade 1992).

Beside to see the active and inactive alveoli, the histology of the mammary gland also shows different alveolar diameters and secret (milk). The mammary gland from the mother rats treated with the highest dose (60 $\mathrm{g} / 300 \mathrm{~mL}$ ) was larger in diameter, more and thicker than the other treatment groups and even fat droplet was seen in the secret part (Figure 2). It can be said that the infusion of fennel leaves in addition to increasing milk production can also improve the quality of milk (fat).

\section{Kidney function}

Uric acid levels in the blood of test animals showed normal levels (4.0-4.6). Uric acid levels in normal mice range from 1.2-5.0 mg/dl. The ANOVA test results on the $95 \%$ confidence level of the data showed no significant difference in the uric acid levels of the test animals between the treatment groups $(p=0.8)$. The results showed that administration of fennel leaf infusion for 15 days in postpartum white rats did not affect kidney function.

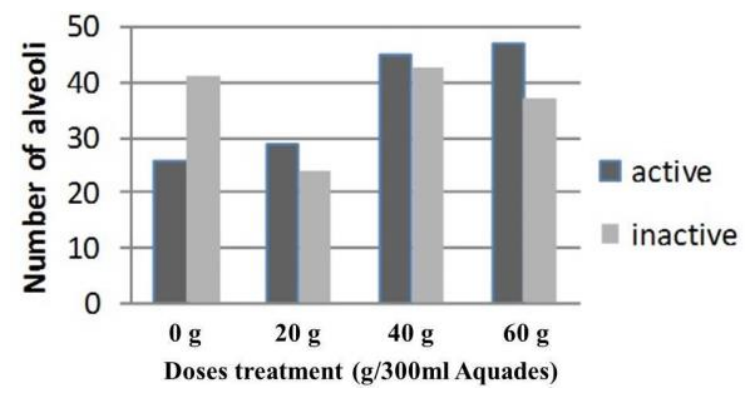

Figure 1. Number of active and inactive alveoli in the mammary gland between treatment groups.

Table 2. Uric acid levels in the blood of test animals

\begin{tabular}{ll}
\hline Doses & Uric acid contents (mg/d) \\
\hline $0 \mathrm{~g} / 300 \mathrm{~mL}$ & $4.0^{\mathrm{a}}$ \\
$20 \mathrm{~g} / 300 \mathrm{~mL}$ & $4.4^{\mathrm{a}}$ \\
$40 \mathrm{~g} / 300 \mathrm{~mL}$ & $4.1^{\mathrm{a}}$ \\
$60 \mathrm{~g} / 300 \mathrm{~mL}$ & $4.6^{\mathrm{a}}$ \\
\hline
\end{tabular}



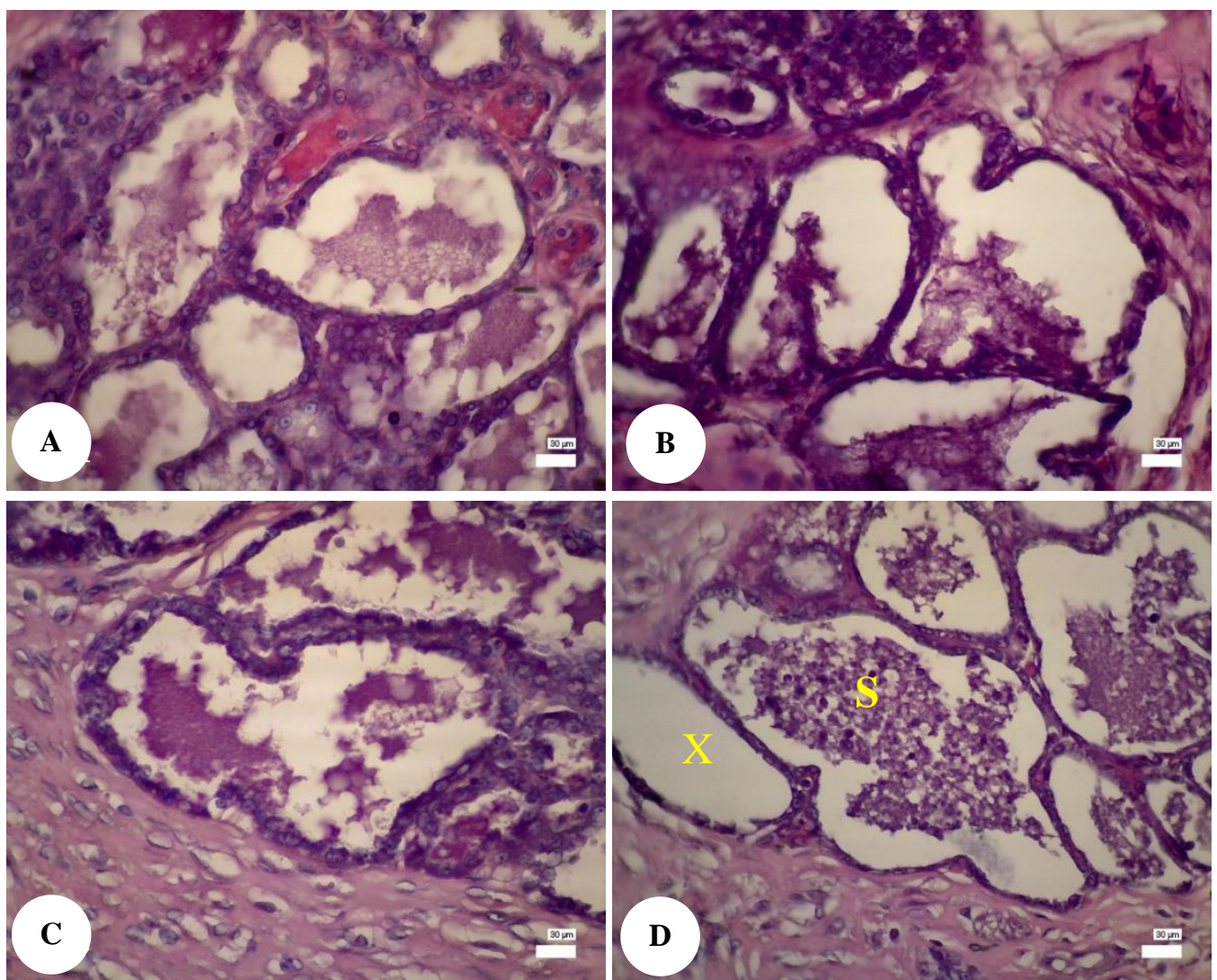

Figure 2. Histological description of the mammary alveolus in the treatment group.. The scale bars (A-D) are $30 \mu \mathrm{m}$. A. Control, B. P1, C. P2, D. P3, S. secret (milk), V. active Alveolus, X. not active alveolus. (The magnification size are too small. I suggest the author to add in the caption as well). H\&E. 400x

Based on the results, it can be concluded that the infusion of fennel leaves (Foeniculum vulgare Mill.) with a dose of $60 \mathrm{~g} / 300 \mathrm{~mL}$ of aquos for 15 days can significantly increased the lumen diameter of the lactoferous ducts in the mammary glands of the lactation period, and increased in diameter alveoli and the number of active mammary gland alveoli. In the histology of the mammary gland, it can also be seen that the secretions/milk quality produced from the mother treated with a dose of $60 \mathrm{~g} / 300 \mathrm{~mL}$ of aquos are increased and more qualified than the other treatment groups. This treatment also does not show significant side effects in kidney.

\section{ACKNOWLEDGEMENTS}

The author would like to thank Research and Community Service Institut (LPPM) of Universitas Islam Negeri (UIN) Sunan Kalijaga, Yogyakarta, Indonesia for funding this research.

\section{REFERENCES}

Al-sudany NM. Al-Qubaidei S. Abdul-Jabbar OQ. 2014. Histological study of fennel (Foeniculum vulgare) effect on female rats mammary glands. Med J Islamic World Acad Sci 22 (2): 76-84.

Badgujar SB, Vainav VP, Atmaram HB . 2014. Foeniculum vulgare Mill: A review of its botany, pytochemistry, pharmacology, contemporary aplication, and toxicology. Biomed Res Intl. 2014: 842674. DOI: $10.1155 / 2014 / 842674$

Benlafya K. Farsaoui ME. Chatouni S. Azamouze W. Charkaoui Y. Karrouchi K. 2015. Antimicrobial potentials of aqueous and methanolic crude extracts of Zingiber officinale and Foeniculum vulgare. J Chem Pharmaceut Res 7 (8): 964-966.

Brade W, 1992. A review of influence of breeding, feeding and other factors on milk production and composition. Animal Research and Development. Institute for Scientific Co-operation, Tubingen, Vol. 36: 68-91.

Dalimartha S. 2000. Atlas of Indonesian Medicinal Plants, Volume 2. Trubus, Jakarta. [Indonesian]

Devi K, Vanithakumari G, Anusya S, Mekala N, Malini T and Elango V. 1985. Effect of Foeniculum vulgare seed extract on mammary glands and oviducts of ovariectomised rats. Anc Sci Life 5 (2): 129-132.

Dhumal MV, Salhare PG, Deshpande KS. 1989. Factors affecting lactation milk yield and lactation length in Red Kandhari and crossbred cows. Indian J Dairy Sci 42: 102-104. 
Javan R, Javadi B, Feyzabadi Z. 2017. Breastfeeding: A review of its physiology and galactogogue plants in view of traditional medicine. Breastfeed Med 12 (7): 401-409.

Junqueira LC, Carneiro J, O Robert, Kelley. 1996. Basic Histology 8th ed. Appleton \& Lange, Norwalk, CT.

Kharisma Y, Armaya A, Herri SS. 2011. The effect of young papaya (Carica papaya L.) fruit extract on the histology of glandular mammals of lactating mice. MKB 43 (4): 160-165. [Indonesian]

Kurniawan B. 2013. Determinant of successful of exclusive breast feeding. Brawijaya Medical Journal vol. 27 (4): 236-240 [Indonesian]

meiyanto E, Handayani S, Jenie RI. 2008. Snake beans (Vigna sinensis L.Savi ex Hassk) extract increases breast epithelial cells proliferation. Majalah Farmasi Indonesia 19 (4):191-197.

Neville MC. 1988. Milk secretion. Amer J Vet Res 56: 203-207.

Partodihardjo S. 1992. Animal Reproductive Sciences. Pearl Publishers, Jakarta. [Indonesian]
Permana D. 2008. Histopatology Study of the Effect of Torbangun Leaf (Coleus amboinicus Lour.) On Milk Production of Mammary Glands Mice (Mus musculus) [Thesis]. Bogor Agricultural Institute, Bogor. [Indonesian]

Pidada IBR, Suhargo L. 2007. The ability of tiram Mushrooms (Pleurotus ostreatus) as a supplement to increase milk secretion and the diameter of mammary gland alveoulus. Berkala Hayati: 12 (161-165.). [Indonesian]

Pidada IBR, Suhargo L. 2009. The role of wungu leaf extract (Graptophyllum pictum (L.) Griff.) to inhibit mammary gland atrophy of female ovariectomy mice. J Res Med Exact 8 (2): 120-124. [Indonesian]

Rifqiyati N.2016. Nutritional content and phytochemical compounds of fennel leaves (Foleniculum vulgare Mill). Pros Sem Nas Biodiversitas 5 (1): 92-95. [Indonesian] 